\title{
RESTRUKTURISASI OBYEK WISATA ALAM DAN AGRO SEBAGAI WUJUD PELAYANAN SOSIAL KEMASYARAKATAN DI DESA GENITO KABUPATEN MAGELANG
}

\author{
Adhi Surya Perdana* \\ *Fakultas Pertanian, Universitas Tidar \\ Email : adhisuryaperdana@ untidar.ac.id ; Hp. +628567692123
}

\begin{abstract}
Abstrak
Pariwisata saat ini dipandang sebagai sektor populer dalam ekonomi nasional maupun dunia, dimana salah satu motor industri gaya kekinian yang mampu memberikan pelayanan sosial kemasyarakatan terutama di Desa Genito dalam menyediakan obyek wisata alam dan agro, serta membuka peluang pertumbuhan ekonomi dalam hal membuka kesempatan kerja, pendapatan, taraf hidup dan mengaktifkan sektor produksi lokal. Tujuan dari kajian ini yakni mengidentifikasi faktor-faktor pendorong dan penghambat obyek wisata alam dan agro serta restrukturisasi obyek wisata. Permasalahan meliputi minimnya aksesibilitas darat dan sulitnya kendaraan bermotor menuju lokasi wisata alam dan agro. Kajian ini bersifat kualitatif, dimana penjelasan kajian menggambarkan tentang keadaan temuan lapangan dan mengajukan kuisioner berisikan pertanyaan terstruktur yang ditujukan kepada masyarakat mulai dari tokoh masyarakat, pemangku pemerintahan desa, pelaku penggerak obyek wisata, dan wisatawandengan total responden sebanyak 30 orang, menggunakan metode insidental random sampling. Hasil kajian menunjukan bahwa obyek wisata alam dan agrowisata di Desa Genito terdapat 2 objek wisata yakni wisata alam dengan penguasaan lahan dimiliki oleh perhutani dan didukung lahan pertanian masyarakat desa yang memberikan keindahan wisata agro. Restrukturisasi obyek wisata alam berupa kolam renang, kolam ikan dan obyek swafoto yang keberadaannya terletak di tengah hutan dengan nama Sukorini. Restrukturisasi obyek wisata alam yang berbentuk kolam renang merupakan inovasi pemerintah desa, mengingat kebanyakan orang mengetahui letak kolam renang berada di daerah perkotaan.
\end{abstract}

Kata Kunci : Restrukturisasi, Obyek Wisata, Pelayanan Sosial Kemasyarakatan 


\begin{abstract}
Tourism is now seen as a sector popular in the national economy and the world, where one of the motor industry style of contemporary capable of providing social services community, especially in the village of Genito in providing natural attractions and agro, as well as the opportunities of economic growth in terms of employment opportunities, income, the standard of living and to enable the local production sector. The purpose of this study which is to identify the factors driving and inhibiting natural attractions as well as the restructuring and agro tourism. Problems include the lack of accessibility of land and the difficulty of the motor vehicle to the location of natural and agro. This is a qualitative study, which describes the study explanation about the state of the field findings and submit the questionnaire contained structured questions addressed to the public ranging from community leaders, stakeholders of the village administration, the offender driving tourism, and tourists with the total respondents as many as 30 people, using the method of random sampling incidental. The study results showed that the natural attractions and tourism in the village of Genito there are two attractions that nature tenure is owned by forestry and agricultural land supported rural communities that provide beauty agro tourism. Restructuring of natural attractions such as swimming pools, fish ponds and objects whose existence Selfie nestled in the woods with Sukorini name. Restructuring of the natural attractions in the form of a pool is an innovation village government.
\end{abstract}

Keywords: Restructuring, Tourism, Provide Social Services 


\section{Pendahuluan}

Peluang sektor pariwisata sangat prospektif sebagai pendorong peningkatan pertumbuhan ekonomi masyarakat dan pembangunan sektor pertanian, kelestarian lingkungan alam, dan ekonomi kreatif yang berkembang di wilayah setempat. Dukungan kebijakan pembangunan pariwisata Kabupaten Magelang dengan mengusung visi terwujudnya Kabupaten Magelang sebagai kabupaten wisata yang berdaya saing dan berwawasan budaya, diturunkan pada peraturan daerah Kabupaten Magelang nomor 4 tahun 2015 tentang rencana induk pembangunan kepariwisataan Kabupaten Magelang Tahun 2014-2034. Potensi obyek wisata di Kabupaten Magelang memiliki kelayakan untuk dapat bersaing dengan wisata lainnya, terutama di Desa Genito Kecamatan Windusari memiliki potensi wisata alam dan agro yang propektif untuk dikembangkan. Salah satu unsur terkuat yang saat ini belum tergarap secara optimal adalah wisata alam dan agro, potensi wisata tersebut ditujukan dari keindahan lingkungan alam atas penguasaan lahan perhutani dan lingkungan pertanian yang menjadi bagian kegiatan pokok masyarakat untuk bertani.

Wisata alam merupakan sumberdaya alam yang memiliki potensi serta daya tarik bagi pengunjung dalam keadaan alami, sedangkan wisata agro merupakan rangkaian kegiatan wisata yang memanfaatkan potensi budidaya pertanian yang dilakukan oleh petani setempat sebagai obyek wisata berupa potensi pemandangan lingkungan pertanian, kekhasan dan keanekaragaman aktivitas produksi, teknologi pertanian dan budaya masyarakat tani setempat. Wisata alam yang umumnya dilakukan meliputi penyediaan gardu pandang, swafoto dan penyediaan akomodasi, sedangkan wisata agro meliputi pemandangan hamparan pertanian, aktivitas pertanian bersama petani dan budaya keseharian masyarakat tani. Guna mendukung kemajuan potensi obyek wisata perlu adanya restrukturisasi obyek wisata, dikarenakan adanya tuntutan daya tarik wisata dengan adanya perubahan minat atau dalam rangka mengakomodasi kepentingan kebutuhan wisatawan, namun yang lebih penting adalah menciptakan gaya wisata kekinian untuk peningkatan taraf hidup masyarakat desa.

Proses restrukturisasi obyek wisata alam dan agro di Desa Genito dengan tetap berpedoman pada peraturan daerah Kabupaten Magelang nomor 9 tahun 2018 tentang penyelenggaraan usaha pariwisata. Wujud atas potensi alam, flora fauna dan budaya masyarakat yang perlu dikembangkan menjadi potensi pariwisata daerah untuk meningkatkan kemakmuran dan daya saing perekonomian daerah dalam rangka menciptakan iklim usaha wisata yang kekinian dan berjalan secara kondusif. Rumusan permasalahan dalam kajian ini, meliputi potensi obyek wisata alam dan agro yang telah ada, cenderung kurang peminat yang disebabkan akses jalan yang sulit dijangkau dan 
sulitnya kendaraan bermotor untuk masuk lokasi wisata serta pengelolaan obyek wisata yang belum tertatur, kesulitan dana untuk pembangunan obyek wisata dan kurang kekinian.Tujuan dari kajian ini, mengidentifikasi faktor-faktor pendorong dan penghambat obyek wisata alam dan agro serta restrukturisasi obyek wisata di Desa Genito.

\section{Landasan Teori dan Kerangka Pemikiran}

\subsection{Landasan Teori}

\subsubsection{Restrukturisasi Obyek Wisata}

Pengertian restrukturisasi menurut

Kamus Besar Bahasa Indonesia berarti penataan kembali. Menurut Marbun (2002)dalam Pratamarini (2007) mendefinisikan restrukturisasisebagai suatu penataan kembali, membuat struktur baru atau penyempumaan atas struktur yang telah ada.Penyempurnaan atas struktur yang dimaksud yakni kondisi bangunan yang merupakan bagian utama atas obyek utama yang mendasari daya tarik wisata berbasis sejarah budaya karena keunikan bangunan dan bentuk fisiknya menjadi identifikasi yang sekaligus membedakan dengan daerahtujuan wisata lainnya (Shankar, 2015; Bullen dan Love, 2011; Sahubawa, et al., 2010). Oleh karena itu, kondisibangunan yang masih asli menjadi potensi kuat untuk pengembangan kepariwisataan. Dalam Undang-Undang nomor 9 tahun 190, obyek dan daya tarik wisata adalah segala yang menjadi sarana perjalanan wisata, terdiri dari obyek dan daya tarik wisata ciptaan Tuhan Yang Maha Esa, yang berwujud keadaan alam, serta flora dan fauna; serta Objek dan daya tarik wisata hasil karya manusia yang berwujud museum, peninggalan sejarah, wisata agro, wisata tirta, wisata petualangan alam, taman rekreasi dan tempat hiburan.

\subsubsection{Pelayanan Publik}

Pelayanan publik (public service) menurut Rohman (2008) adalah suatu pelayanan atau pemberian terhadap masyarakat yang berupa penggunaan sarana dan prasarana publik yang dilakukan oleh pemerintahan. Pemerintah, pihak yang memberikan pelayanan adalah aparatur pemerintah beserta segenap kelengkapan kelembagaannya. Pelayanan publik dikemukakan oleh Kurniawan (2005), bahwa pelayanan umum adalah pelayanan yang mendahulukan kepentingan umum, mempermudah urusan publik mempersingkat waktu pelaksanaan urusan publik dan memberikan kepuasan kepada publik, sedangkan Sinambela (2006) kualitas pelayanan berhubungan erat dengan pelayanan yang sistematis dan komprehensif yang dikenal dengan konsep pelayanan prima.

Tingkat kualitas tidak dapat dinilai berdasarkan sudut pandang obyek wisata tetapi harus dipandang dari sudut pandang penilaian wisatawan yang berkunjung menikmati obyek wisata. Karena itu, dalam merumuskan strategi dan programpelayanan, obyek wisata harus berorientasi pada kepentingan wisatawan dengan memperhatikankomponen kualitas pelayanan publik sesuai penjelasan Kotler (2001) bahwa unsur pokok untuk mengukur service adalah : kehandalan, yakni ketepatan, kecermatan, dan kecepatan dalam melayani; ketanggapan, yakni Kemampuan perusahaan dalam menghadapi 
permasalahan yang timbul, serta ketersediaan dalam menerima setiap keluhan berupa kritik dan saran; keyakinan, yakni Penetapan produk yang sesuai dan bertanggung jawab atas keamanan dan keselamatan pelanggan; empati, yakni memberikan perhatian khusus kepada konsumen dalam proses pembelian dan menyajikan informasi yang diperlukan konsumen; dan wujud, yakni tersedianya sarana pendukung seperti alat penyejuk ruangan, tempat perparkiran, ruangan yang cukup memadai, dan lain sebagainya.

\subsubsection{Partisipasi}

Menurut Ndraha (1994) mengemukakan bentuk-bentuk partisipasi masyarakat dalam pembangunan, yaitu partisipasi melalui kontak dengan pihak lain; partisipasi dalam memperhatikan atau menyerap dan memberi tanggapan terhadap informasi; partisipasi dalam perencanaan pembangunan, termasuk pengambilan keputusan; partisipasi dalam pelaksanaan organisasional pembangunan; partisipasi dalam menerima, memelihara dan mengembangkan hasil pembangunan; dan partisipasi dalam menilai pembangunan.

\subsubsection{Sosial Kemasyarakatan}

Masyarakat dalam lingkungan suatu obyek wisata sangatlah penting dalam kehidupan suatu obyek wisata karena mereka memiliki kultur yang dapat menjadi daya tarik wisata, dukungan masyarakat terhadap tempat wisata berupa sarana kebutuhan pokok untuk tempat obyek wisata, tenaga kerja yang memadai dimana pihak pengelola obyek wisata memerlukannya untuk menunjang keberlangsungan hidup obyek wisata dan memuaskan masyarakat yang memerlukan pekerjaan dimana membuat kehidupan masyarakat menjadi lebih baik (Rahmah, 2017).

Pengembangan obyek wisata
menumbuhkan banyak harapan bagi masyarakat sekitar, terutama harapan dari segi pertumbuhan ekonomi masyarakat sekitar, segi sosial masyarakat yang lebih baik, serta pelestarian budaya sehingga dapat mensejahterakan kehidupan masyarakat sekitar.Konsekuensi suatu destinasi wisata adalah harus siap menerima dampak pariwisata yang terjadi baik dari aspek sosial budaya maupun ekonomi maka diperlukan kerjasama antara pemerintah daerah, investor, maupun masyarakat sekitar untuk meminimalkan dampak pariwisata yang akan terjadi dalam upaya upaya pengembangan pariwisata menimbulkan dampak positif maupun negatif bagi masyarakat dan wisatawan di sekitar obyek wisata (Abdillah dkk, 2016).

\subsection{Kerangka Pemikiran}

Kerangka pemikiran digunakan sebagai dasar dalam pengembangan konsep kajian Restrukturisasi Obyek Wisata Alam dan Agro Sebagai Wujud Pelayanan Sosial Kemasyarakatan di Desa Genito. Konsep yang dibangun berdasarkan obyek wisata alam dan agro yang telah ada, dengan melakukan identifikasi permasalahan dukungan sarana dan prasarana wisata disertai pelayanan publik yang dilakukan pemerintah desa bersama masyarakat dan melakukan restrukturisasi obyek wisata dalam mewujudkan pelayanan sosial kemasyarakatan (lihat Gambar 1.). 


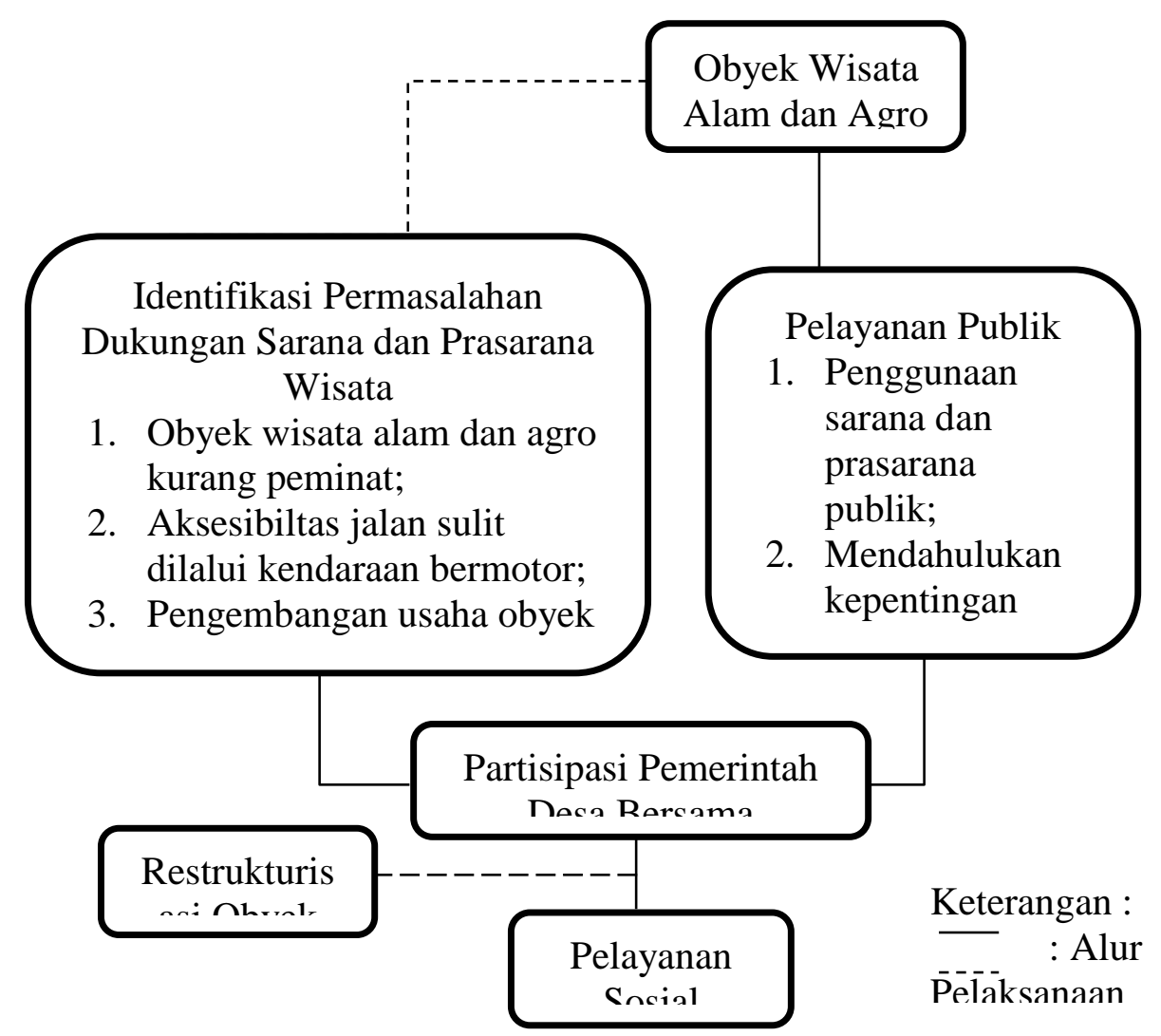

Gambar 1. Kerangka Pemikiran Kajian

\section{Metodologi Kajian}

Kajian ini dilaksanakan pada Bulan Januari-Februari 2019 di Desa Genito, fokus kajian terletak pada restrukturisasi obyek wisata alam dan agro sebagai wujud pelayanan sosial kemasyarakatan. Metode penelitian secara kualitatif, menggunakan pendekatan psikologi lingkungan (ecology psychology). Menurut Jacob (2010) terkait psikologi sosial yakni mempelajari hubungan perilaku manusia dengan lingkungan fisiknya. Disadari bahwa manusia berperan dalam merubah lingkungannya. Sebaliknya juga diyakini bahwa lingkungan turut mempengaruhi dan merubah manusia. Perilaku, sikap, cara berpikir manusia sangat tergantung dari lingkungan di mana dia berada. Sampel kajian terdiri dari 8 orang tokoh masyarakat, 5 orang pemangku pemerintahan desa, 5 orang pelaku penggerak obyek wisata, dan 12 orang wisatawan dengan metode penarikan sampel menggunakan tenik insidental random sampling. Pengumpulan data menggunakan cara observasi, wawancara, dan dokumentasi. Instrumen kajian disusun dalam kuisioner terstruktur. 


\section{Pembahasan}

4.1. Karakteristik Responden dan Kondisi Wilayah Umum Obyek Wisata

Responden yang dijadikan sumber data primer terdiri dari 8 orang tokoh masyarakat, 5 orang pemangku pemerintahan desa, 5 orang pelaku penggerak obyek wisata, dan 12 orang wisatawan. Jenis pekerjaanresponden sebagai perangkat desa, petani, pedagang, pelajar, mahasiswa, wiraswasta dan karyawan swasta. Rata-rata pendapatan responden sebesar Rp.400.000-Rp.1.500.000 per bulan. Pemangku pemerintah desa, masyarakat desa, dan penggerak objek wisata atau kelompok kerja wisata (POKJA Wisata) umumnya mengikuti organisasi masyarakat yang bergerak dibidang keagamaan, perlindungan masyarakat, lembaga masyarakat desa hutan (LMDH), Puncak Sukorini Witono dan kesenian desa. Adapun kelemahan dari POKJA wisata, belum memiliki pengalaman dalam organisasi dan mengelola objek wisata.

Kondisi wilayah umum Desa Genito terletak di sebelah utara Desa Mangunsari, dan sebelah timur Desa Candisari. Jenis tanaman pertanian diantaranya padi, tembakau, cabai, tomat, bawang, umbi-umbian, ketela pohon, sawi dan strowberi. Selain tanaman pertanian, masyarakat desa menjalankan usaha perikanan dan peternakan. Perikanan yang dilakukan masyarakat menggunakan jenis ikan lele, gurame, nila dan mas, sedangkan peternakan umumnya masyarakat berternak sapi, kambing, dan ayam. Produk wirausaha terdiri dari memiliki produk-produk hasil pertanian berupa potil, grubi, bawang goreng, kripik kimpul, pelet ikan, kerajinan sandal dan tas yang rencananya akan dijadikan produk unggulan dalam mendukung perkembangan wisata-wisata di desa Genito.

\subsection{Dukungan Sarana dan Prasarana Sebagai Bentuk Pelayanan Publik di Kawasan Obyek Wisata Alam dan Agro}

Sarana dan prasarana yang mendukung atas aktivitas pelayanan publik dengan melibatkan usaha-usaha manusia dan menggunakan sarana prasarana pendukungberdasarkan landasan faktor material, melalui sistem, prosedur, dan metode tertentu untuk memberikan solusi atas permasalahan dan kepentingan kelompok / lembaga / perorangan lainnya sesuai dengan haknya pada wilayah obyek wisata alam dan agro.

\subsubsection{Wisata Alam}

\subsubsection{Puncak Sukorini}

Objek wisata alam Desa Genitoyakni Puncak Sukorini, merupakan bukit alam yang digunakan untuk menikmati panorama pemandangan alam, basecampdan menikmati sunrise. Tempat wisata ini dikembangkan sejak 2016, dimulai dengan pembetonan jalan, pembuatan spot foto, gazebo, dan ayunan. Menurut Bejo (45tahun) selaku Sekretaris LMDH “akses menuju Sukorini belum dapat dikatakan baik karena untuk menuju puncak masih berupa jalan tanah dengan sudut kemiringan jalan $70^{\circ}$ derajat elevasi jalan. Saat ini, akan dilakukan pelebaran jalan pada lokasi jalan tanah menuju puncak Sukorini dengan dukungan penggalangan dana oleh Karang 
Taruna dalam rangka pengembangan dan mempertahankan eksistensi Sukorini hingga sekarang”, hal ini dilakukan sebagai upaya untuk meningkatkan kenyamanan bagi wisatawan melalui destinasi perjalanan ke puncak Sukorini dan dapat melihat destinasi tambahan berupa candi yang terkubur, hanya tampak bagian atas bangunan candi. Obyek wisata Sukorini pada musim hujan, lokasi ditutup sementara untuk menjaga keselamatan wisatawan dikarenakan lokasi wisata alam termasuk kategori rawan bencana tanah longsor.

Data laporan wisata LMDH tahun 2017, rata-rata wisatawan yang mengunjungi Puncak Sukorini sebanyak 343 orang/bulan. Dimana paling besar wisatawan berasal dari kalangan pelajar/mahasiswa, dengan rata-rata lama kunjungan 5-6 jam. Wisatawan yang ingin menikmati sunrise, dapat menyewa penginapan (homestay). Wisata puncak Sukorini telah dilengkapi sarana dan prasarana yang memadai seperti kamar mandi, dan mushola. Selain itu dipuncak terdapat lahan pertanian yang ditanam strowbery,sengaja disediakan pengurus sebagai salah satu penunjang wisata puncak Sukorini.

\subsubsection{Kolam Renang Piwakan}

Kolam renang Piwakan merupakan kolam renang yang dahulunya merupakan kolam ikan milik warga. Menurut Sugitno (50 tahun) selaku Kepala Dusun Gopakan "Awal mula Kolam Renang, berfungsi sebagai kolam ikan dan sebagai kegiatan upacara adat. Seiring berjalannya waktu, semakin lama pemilik tanah tidak mampu membayar pajak dan diserahkan peruntukannya kepada Pemerintah Desa untunk fasilitas umum". Hingga pada tahun 2017 pembangunan kolam dimulai, dilanjutkan renovasi tahun 2018. Kolam renang Piwakan berada di samping jalan utama Desa Genito, sehingga mudah diakses. Kekurannganya belum terdapat tempat parkir yang memadai. Objek wisata ini sempat dibuka untuk ujicoba dan ramai dikunjungi oleh masyarakat sekitar, kebanyakan pengunjung dari kalangan pelajar dan anak-anak, rata-rata kunjungan bisa mencapai $>100$ orang/bulan.

Penggunaan sarana dan prasarana sebagai bentuk pelayanan kepada publik masih berupa toilet dan mushola.Keunggulan tempat wisata,memberikan sarana kegiatan olahraga renang dan tempat acara budaya untuk kepentingan umum. Hal ini, dikarenakan sebelum kolam renang dibangun sering digunakan untuk kegiatan adat. Seperti pernikahan tembakau, panen raya, dan lain-lain. Ketika pembangunan kolam renang selesai, tempat dibuka untuk ujicoba danpengunjungmerasakan puas terhadap fasilitas kolam renang yang dibangun. Perkembangan tempat wisata kolam renang piwakan tidak terlepas dari peran serta pemerintah desa, hingga saat ini pemerintah desa pun sedang merancang rintisan kerjasama dengan pihak lain seperti BUMDES, PKK, dan pelaku-pelaku perekonomian desa maupun luar desa guna mendukung pengembangan kolam renang. 


\subsubsection{Sendang Piwakan}

Sendang Piwakan sebagai kolam ikan yang terletak bersebelahan dengan kolam renang. Pada sendang tersebutlah, pesanggrahan dibangun. Sendang Piwakan, berisikan ikan yang sengaja dilepasikan mas dan mujahir, terdapat keunikan dari kolam ikan yaitu terdapat tiga ekor ikan bernama Ulam Tombro (Indo: Ikan Tombro). Ikan tersebut memiliki keunikan, ikan yang bertubuh dan bobot besar ketika dilakukan pengeringan kolam tidak diketahui keberadaannya / hilangdi sendang. Namun ketika kolam diisi kembali dengan air,kemudian Ulam Tombro akan muncul kembali.

Kegiatan perkawinan tembakau biasanya dilakukan selama satu tahun sekali atau pada kalender jawa jatuh pada bulan sapar hari selasa pahing. Menurut Pak Ratno (49 tahun)“Ketika kesenian-kesenian dari Dusun Gopakan akan tampil biasanya akan ada anggota yang melakukan upacara yang berhubungan dengan hal gaib di tempat tersebut". Sewaktu menggelar upacara adat "pernikahan tembakau", banyak masyarakat yang berharap berkah dari Tuhan Yang Maha Kuasa. Ucapan syukur atas perolehan hasil panen yang telah diperoleh dan berharap hasil panen tahun berikutnya mendapatkan hasil yang lebih baik. Tembakau yang dinikahkan dipercaya sebagai "pihak lakilaki" yang diberi nama tembakau Kyai Pulung Soto dan "pihak perempuan" diberi nama Nyai Srintil. Kegiatan pernikahan tembakau setiap tahunnya dilakukan setiap tahun pada bulan Sapar (telah berjalan 7 kali pelaksanaan) dan berbeda waktu pelaksanaan pada Tahun 2018 upacara yang dilaksanakan bulan Maulud hari Selasa Pahing, Dinas Pariwisata Kabupaten Magelang pun mendukung atas kegiatan upacara pernikahan tembakau. Antusias masyarakat yang datang sangat tinggi, sejak pagi hari pada bulan Sapar sudah tampak suasana meriah di Dusun Gopaan. Sepanjang jalan perkampungan dengan lokasi fisik jalan yang naik turun telah berderet stan-stan partsipan yang menjajakan aneka dagangan, mulai dari kuliner, mainan anak, kerajinan, cinderamata, baju, dan sebagainya.

Warga masyarakat pun telah bersiap-siap mengenakan pakaian adat jawa untuk melaksanakan kirab, sambil mengusung gunungan hasil bumi dengan berjalan menuju tengah Sendang Piwakan dengan tercium bau dupa saat upacara pernikahan berlangsung, para sesepuh melapazkan takzim dan kemudian diiringi gending tradisional yang berasaldari sanggar seni setempat. Pelaksanaan ucapara pada Tahun 2018 berbeda pelaksanaan ritualnya terutama pada sepasang tembakau tidak dicelupkan kedalam sendang atau dibasahi, dikarenakan menurut anjuran para sesepuh bahwa tembakau tidak dimasukan kedalam sendang untuk menghindari hujan yang berkepanjangan dan mengakibatkan menurunnya kualitas panen tembakau "mitos". Pemerintah Desa Genito sangat mendukung kegiatan tersebut, dikarenakan adanya acara ritual pernikahan tembakau dirasakan dapat memberikan nilai tambah ekonomi masyarakat disekitar dengan membuka mata pencaharian baru yang bervariasi saat acara berlangsung. 


\subsubsection{Wisata Agro}

Objek wisata Agro di Desa Genito masih berupa perencanaan yang akan dilakukan disekitar wisata Puncak Sukorini, Kolam Renang Piwakan dan Sendang Piwakan. Menurut perangkat Pemerintahan Desa, perencanaan tersebut masih terus dikembangkan disamping mengembangkan objek wisata alam dan agro. Wisata agro berupa pemandangan lingkungan pertanian tanaman pangan, holtikutura, strawbery, ubi dan umbi. Jenis tanaman yang dibudidaya oleh petani yakni padi, jagung, cabai, singkong, ubi, bawang, dan tanaman pendukung wisata strawbery. Wisata agro diharapkan dapat berguna kelestarian lingkungan pertanian dan dapat memberikan keuntungan ekonomi non hasil pertanian bagi petani dan masyarakat. Berdasarkan kondisi wilayah lingkungan pertanian yang ada di Desa Genito, memiliki luas areal sawah seluas 49 ha, tegalan/perkebunan seluas 232,50 ha,tambak/kolam 0,70 ha, perkebunan negara/swasta seluas 7 ha, dan padang gembala seluas 3,28 ha.

Keberadaan lingkungan pertanian yang luas dengan memiliki keindahan panorama, memberikan kenyamanan, kesejukan, dan memberikan nuansa bagi wisatawan yang datang berkunjung. Nilai estetika diperoleh dari pemandangan visual dari tanaman pertanian mulai dari beragam jenis tanaman, warna, arsitektur tanaman dan keteraturan jarak tanam pada kurun musim tanam pada waktu tertentu. Setiap perencanaan wisata agro yang dilakukan kelompok kerja wisata perlu memikirkan nilai keserasian, keselarasan dan manfaat turunannya pada lingkungan sekitar. Obyek wisata agro tidak dapat dipisahkan keberadaannya sebagai sarana rekreasi dan edukasi pertanian. Sarana pendukung wisata agro berupa lahan petik langsung buah dan sayuran dikebun pertanian (misalnya : strawbery, sawi, dan sebagainya) seperti halnya taman Mekarsari. Pengunjung sendiri dapat memetik buah dan sayur yang diinginkan, kemudian hasil petikan ditimbang dan pengunjung melakukan transaksi hasil pertanian. Melalui penyediaan fasilitas penunjang, maka keberadaan wisata agro senantiasi berorientasi pada pelayanan pengunjung wisatawan yang memberikan kenangan dan menjaga kelestarian lingkungan pertanian. Dukungan kelompok kerja wisata diharapkan dapat memberikan otonomi yang lebih luas kepada wisata agro untuk mengembangkan core business dan tidak sekedar mengharapkan dari dana desa setempat sebagai induk dana wisata agro (Nugraha, 2013). Selanjutnya sinergi kegiatan rekreasi dan optimasilasi non hasil pertanian dapat berdampak pada perekonomian masyarakat sekitar, seperti halnya penginapan (homestay), pemandu wisatawan, dan sewa kendaraan transportasi.

Wisata agro diharapkan dapat memberikan edukasi ruang terbuka alami, dimana kegiatan pertanian dilakukan langsung oleh petani setempat sesuai kehidupan seharihari. Petani melakukan kegiatan rutinitasnya tanpa ada pengaturan dari pihak lain, dengan nilai-nilai budaya pertanian yang memiliki nilai tawar kekhasan kepada wisatawan. Memberikan 
edukasi ruang terbuka buatan, melalui desain terencana pada kawasan prioritas yang bersifat spesifik, tata ruang peruntukan lahan pertanian diatur sesuai dengan adanya dukungan dan komoditas pertanian yang dikembangkan memiliki nilai jual dan kenangan kepada wisatawan. Adanya daya dukung teknologi budidaya yang ramah wisatawan yang bisa menjadi daya tarik, wisatawan terlibat langsung pada aktivitas budidaya pertanian dan petik langsung dilokasi. Teknologi budidaya pertanian tradisional dapat digunakan sebagai perwujudan keserasian hasil interaksi sosial yang mendukung atraksi wisata potensial.Potensi objek wisata agro yaitu petik buah strawbery langsung yang berada di sekitar obyek wisata Sukorini, diharapkan dapat menjadi daya tarik wisatawan yang banyak diminati.

\subsection{Partisipasi Pemerintah Desa Bersama Masyarakat}

Upaya pemerintah Desa Genito untuk melakukan peningkatan pendapatan petani yang berasal dari nilai tambah pertanian non komoditas, berorientasi pada kepentingan wisata alam dan agro. Partisipasi pemerintah desa dalam membangun tempat wisata puncak Sukorini belum terlalu banyak. Masih minimnya kerjasama-kerjasama yang dibentuk oleh pemerintah dengan BUMDES, PKK dan organisasi bersama pihak swasta lain. Namun pemerintah desa tetap melakukan promosipromosi sebagai usaha membantu wisata tersebut. Pemerintah Desa Genitosaat ini, fokus memperhatikan pembangunan kolam renang dan sendang Piwakan dengan menanggapi, membuka ruang pada setiap masukan-masukan / aspirasi perencanaan dalam pembangunan obyek wisata tersebut. Setiap pembangunan direncanakan, dikontrol dan dipelihara oleh pemerintah desa bersama masyarakat sekitar. Saat ini, Desa Genito masih memiliki banyak kendala yakni cara pandang masyarakatdalam mempresepsikanprogram pemerintah desa pada salah satu obyek wisata saja, terutama kolam renang dan sendang Piwakan sebagai sentra kegiatan wisatawan.

Salah satu pendukung obyek wisata dapat berjalan dengan baik, jika memperhatikan aspirasi masyarakat yang berwawasan lingkungan. Dukungan masyarakat yang terlihat, peran aktif dalam menjalankan aktifitas wisata pada obyek wisata alam Sukorini yakni organisasi masyarakat LMDH dan karang taruna. Wilayah Desa Genito banyak ditemui sebaran tempat-tempat yang memiliki potensi sebagai lokasi wisata alam dan agro, hanya saja masyarakat setempat masih beranggapan bahwa pemerintah desa kurang serius. Kenyataan lapang yang terlihat, kurang adanya perencanaan dan perancangan obyek wisata terintegrasi yang terencana dan berkesinambungan melalui studi kelayakan wisata alam dan agro. Sehingga dapat dikatakan bahwa pemerintah Desa Genito belum memiliki konsep yang matang mengenai arah wisata yang akan diterapkan di wilayahnya.

\subsection{Restruktursisasi Obyek Wisata}

Restrukturisasi yang perlu dilakukan dalam rangka menata kembali keteraturan peruntukan obyek wisata yakni berbentuk penataan kelembagaan masyarakat yang fokus di 
bidang wisata alam, agro, infrastruktur dan stakeholder pendukung. Perencanaan sebuah kawasan wisata yang baru dipikirikan berupa bangunan fisik, infrastruktur pendukung dan amenity core yang merupakan bagian penting untuk dilakukan, terutama potensi alam, agro, dan budaya yang menjadi daya tarik wisatawan secara signifikan dapat dijadikan sebagai parameter acuan dan mendorong minat wisatawan untuk datang berkunjung. Namun disisi lain, intensitas keterlibatan masyarakat lokal sangat dibutuhkan di obyek wisata dimana merakalah yang akan merasakan dampak langsung pengembangan obyek wisata alam dan agro baik dampak positif maupun negatif yang akan ditimbulkan.

Selama dua tahun mulai dari tahun 2016 sampai 2018, hal yang dilakukan karang taruna dan LMDH berupa pembukaan hutan, pembangunan jalan, wahana bermain, swafoto, gardu pandang, serta sarana prasarana pendukung lainnya. Pembangunan Puncak Sukorini dilakukan secara swadaya kerja bakti oleh kedua lembaga masyarakat tersebut.Restrukturisasi yang dilakukan dimulai pada tahun 2017, pembangunan dilakukan dengan konsentrasi kolam renang Piwakan dan betonisasi jalan kampung penunjang obyek wisata Puncak Sukorini. Pembangunan dilakukan dalam dua tahap, pertama pembangunan dasar dan kedua dilakukan penambahaan sarana prasarana dengan menambahkan sarana keamanan seperti pagar pada sekeliling kolam renang piwakan. Hingga akhir tahun 2018, kolam renang ini masih ditutup dikarenakanmasih mempersiapkan pembukaan secara resmi oleh pemerintah desa dan dinas pariwisata. Kegiatan sosial yang terbentuk atas terbentuknya wisata ini adalah kerja bakti dan memperingati hari lahirnya desa.

Adapun permasalahan yang timbul yakni adanya beberapa sarana prasarana pendukung yang hilang akibat dicuri. Selanjutnya permasalahan dari pengelola $\mathrm{LMDH}$, mereka mempermasalahkan pemerintah desa yang kurang memperhatikan tempat wisata Puncak Sukorini dan hanya fokus pada pembangunan kolam renang serta sendang Piwakan.Disisi lain, menurut versi pemerintah Desa Genito kurang perhatian pemerintah desa terhadap tempat tersebut, dikarenakan tempat tersebut masuk dalam wilayah perhutani maka diperlukan uji kelayakan obyek wisata antara pemerintah Desa Genito dengan Perhutani. Maka dari itu, perlu adanya forum diskusi / dialog terencana yang membicarakan pembangunan, pengembangan dan promosi obyek wisata tersebut pada forum resmi yang menghadirkan pemerintah desa, perhutani, masyarakat desa, karang taruna, LMDH, PKK, tokoh masyarakat, kelompok tani / gabungan kelompok tani (GAPOKTAN), dinas pariwisata, dan stakeholder pendukung lainnya. Maka dari itu diperlukan mekanisme restrukturisasi yang diusulkan yakni : 


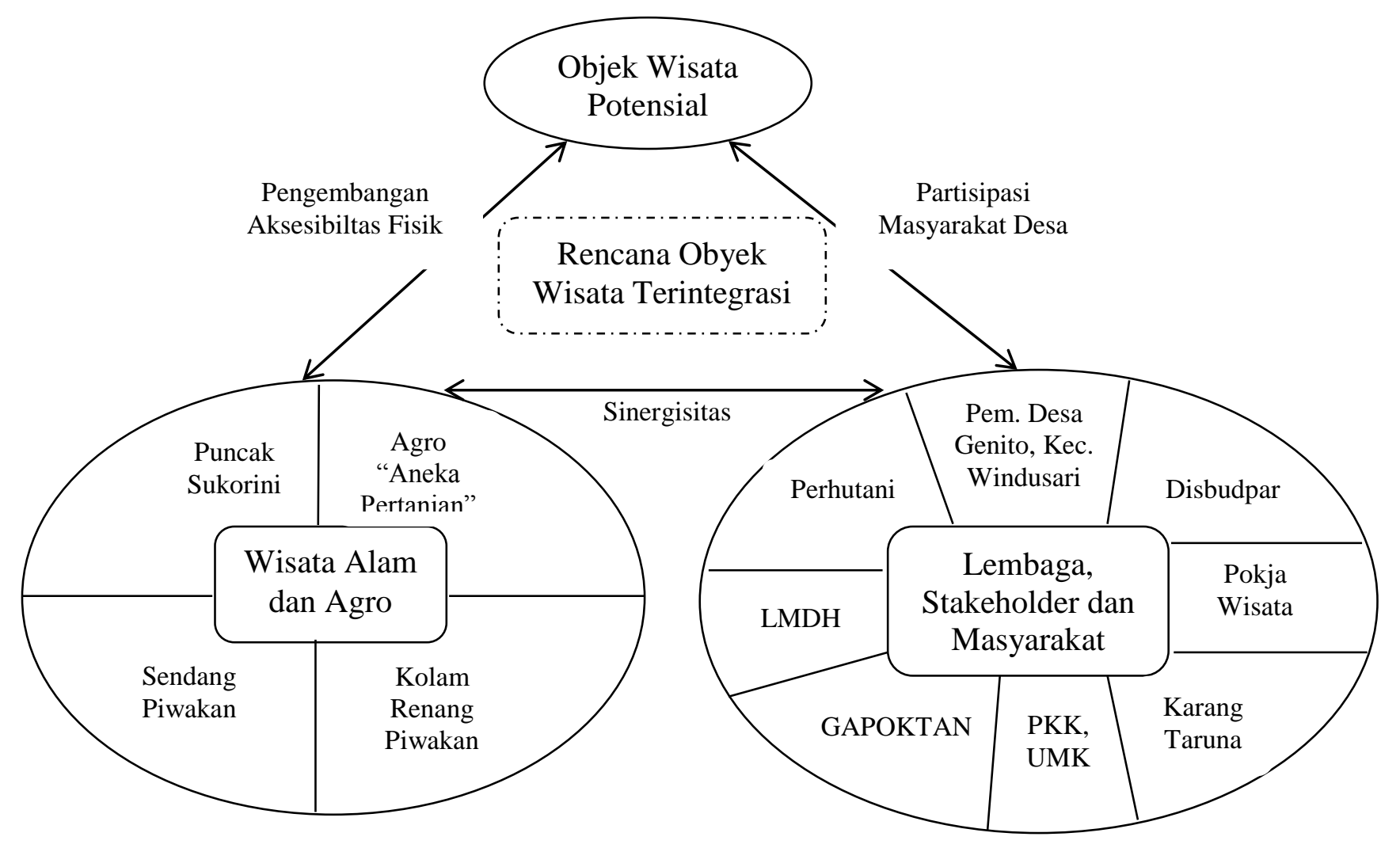

Gambar 2. Mekanisme Restrukturisasi Obyek Wisata Alam dan Agro

Mekanisme restrukturisasi obyek wisata yang ditawarkan (Gambar 2.), diharapkan dapat memprioritaskan obyek wisata potensial berupa obyek wisata Puncak Sukorini dan Kolam Renang Piwakan yang menjadi obyek wisata alam, Sendang Piwakan dapat dijadikan sebagai obyek wisata budaya, dan Agro "aneka pertanian" atau dapat menjelaskan segala macam jenis aktivitas pertanian dan pemandangan lingkungan yang berasal dari tanaman pertanian yang pekerjaannya dilakukan oleh petani, hal tersebut dapat dijadikan sebagai obyek wisata agro. Obyek wisata potensial tidak dapat berjalan dengan baik, jika tidak ada sinergisitas atau kerjasama antar pemerintah Desa Genito, Kecamatan Windusari, Perhutani, LMDH, Dinas kebudayaan dan pariwisata (Disbudpar), POKJA Wisata, Karang Taruna, PKK dan UMK. Adanya

penyusunan rencana obyek wisata terintegrasi dengan melibatkan perwakilan masyarakat (tokoh, pemuda, pemuka agama, dan aktivis lingkungan) dalam menyusun rencana kebutuhan yang pengerjaanya berasal dari aspirasi masyarakat desa setempat dan adanya dukungan pengembangan aksesibiltas fisik maupun peningkatan partisipasi masyarakat desa dalam rangka pembangunan obyek wisata tersintegrasi.

\subsection{Pelayanan Sosial Kemasyarakatan Obyek} Wisata Alam dan Agro

Pelayanan sosial kemasayarakat yang dimaksud terletak pada pelayanan pemerintah desa dan perangkat pemangku dusun dalam memberikan pelayanan jasa maupun sarana prasarana fisik yang diterima warga pengguna maupun masyarakat luas, sesuai yang disampaikan Joko Widodo (2006) dalam Pratamarini (2007) tentang pelayanan sosial 
yang diartikan sebagai pelayanan sosial dapat diartikan sebagai pemberian layanan (melayani) keperluan orang atau masyarakat yang mempunyai kepentingan pada organisasi itu sesuai dengan aturan pokok dan tata cara yang telah ditetapkan.Wujud pelayanan sosial kemasyarakatan, diharapkan dapat meningkatkan perekonomian, kegiatan masyarakat, menumbuhkan usaha mikro kecil pedesaan (UMK), dan badan usaha milik desa (BUMDES) sebagai pemenuhan pekerjaan layak bagi masyarakat desa. Pemerintah Desa Genito senantiasa melakukan pelayanan kepada masyarakat melalui membangun akses fisik jalan kampung, MCK, mushola, saluran air drainase, menyediakan dan membangun bangunan fisik kolam renang Piwakan, merenovasi sendang Piwakan menjadi sentra seni budaya serta memberikan izin usaha dibidang jasa dan produk bagi masyarakat.

Keberadaan Puncak Sukorini dirasakan masyarakat dapat membantu meningkatkan pendapatan masyarakat sebesar Rp.45.000,-/hari dan akan meningkat pada hari libur nasional sebesar Rp.80.000,-/hari dengan adanya sarana parkir, warung klontong makan dan minum, souvenir dan jajanan dadakan. Sarana dan prasarana merupakan salah satu indikator obyek kepuasan wisatawan pada pelayanan yang diberikan terhadap obyek wisata alam dan agro yang disungguhkan Puncak Sukorini, kolam renang Piwakan dan sendang Piwakan. Perlu perhatian khusus pada pembenahan obyek wisata sesuai kebutuhan kenyamanan pengunjung, agar tertanam kenangan dan daya tarik untuk datang kembali ke lokasi wisata. Keindahan alam dan keunikan obyek wisata dapat dipertahankan menjadi icon Desa Genito seperti perkawinan tembakau di sendang Piwakan dan Puncak Sukorini di Dusun Witono.

\section{Kesimpulan dan Saran}

\subsection{Kesimpulan}

Berdasarkan pembahasan diatas, dapat ditarik kesimpulan :

1. Faktor pendorong obyek wisata alam dan agro yang memiliki daya tarik dan unik yakni obyek wisata Puncak Sukorini, Kolam Renang Piwakan, dan Sendang Piwakan, sedangkan faktor penghambatnya meliputi tidak adanya studi potensi obyek wisata serta konsep perencaanaan wisata terintegrasi alam dan agro yang matang melaui forum diskusi dan dialog bersama masyarakat dan stakeholder terkait.

2. Adanya mekanisme restrukturisasi obyek wisata alam dan agro dapat membantu pengembangan obyek wisata terintegrasi, kemudia dalam rangka menata keteraturan obyek wisata sesuai peruntukannya yang berdampak pada peningkatan pendapatan masyarakat dengan melakukan : pembangunan jalan, wahana bermain, swafoto, gardu pandang, serta sarana prasarana pendukung lainnya di Puncak Sukorini, sedangkan kolam renang dan sendang Piwakan berupa rencana menumbuhkan 
usaha mikro kecil pedesaan (UMK), dan

badan usaha milik desa (BUMDES).

\subsection{Saran}

Saran yang disampaikan dalam kajian ini, yakni :

1. Pemantapan konsep Desa Wisata Genito yang terencana dan terintegrasi.

2. Keterlibatan masyarakat dan stakeholder bidang kepariwisataan perlu diperhatikan, sebagai penunjang finansial, material dan dukungan kebijakan.

3. Penguatan kelembagaan pedesaan yang fokus pada kegiatan obyek wisata alam dan agro, sebagai motor penggerak kepariwisataan Desa Genito.

\section{Daftar Pustaka}

Abdillah, Akhmad Bories., Djamhur Hamid dan Topowijono. 2016. Dampak Pengembangan Pariwisata Terhadap Kehidupan Masyarakat Lokal di Kawasan Wisata (Studi Pada Masyarakat Sekitar Wisata Wendit, Kabupaten Malang). Jurnal Administrasi Bisnis (JAB). Vol. 30 No. 1. Malang.

Bullen, P.A., dan Love, P.E.D. 2011. Adaptive Reuse Of Heritage Buildings, Structural Survey. 29(5): 411-421.

Jacob. J.R. 2010. Metode Penelitian Kualitatif (Jenis, Karakteristik, dan Keunggulannya). Grasindo. PT Gramedia Widiasarana Indonesia. Jakarta.

Pratamarini, Dewi Utami. 2007. Restrukturisasi Organisasi Untuk Peningkatan Pelayanan Publik (Studi Kasus Pembentukan Dinas Perizinan Kota Yogyakarta). Tesis. Program Pascasarjana Universitas Gadjah Mada. Yogyakarta
Kotler, Philip. 2001. Manajemen Pemasaran Perspektif Asia. Penerbit ANDI. Yogyakarta.

Kurniawan, Agung. 2005. Transformasi Pelayanan Publik. Pembaruan. Yogyakarta. JOM FISIP Vol. 4 No. 1. Riau.

Ndraha, Taliziduhu. 1994. Manajemen Pemerintahan, Pembangunan dan Pembinaan Masyarakat (MP3M) di Lingkungan Departemen Dalam Negeri. IIP. Jakarta.

Nugraha, Kristian Suhartadi Widi. 2013. Strategi Pengembangan Wisata Agro Wonosari. Jurnal In Search Informatika dan Bisnis Indonesia Design. Volume 11. Universitas Widyatama. Bandung.

Rahmah, Winda. 2017. Dampak Sosial Ekonomi Dan Budaya Objek Wisata Sungai Hijau Terhadap Masyarakat di Desa Salo Kecamatan Salo Kabupaten Kampar.

Rohman, Ahmad Ainur, M. Mas'ud Sa'id, SaifulArif, dan Purnomo. 2008. Reformasi Pelayanan Publik, Program Sekolah Demokrasi, PlaCIPS, Averroes, dan KID. Malang.

Sahubawa, A.A., Antariksa, dan Usman, F. 2010. Kawasan Bersejarah Kota Tua Hindia Belanda di Bandaneira, Maluku. Arsitektur e-Journal. 3(1): 1-13.

Shankar, S. 2015. Impact of Heritage Tourism in India: A Case Study. International Journal of Innovative Research in Information Security (IJIRIS). 6(2): 59-61.

Sinambella, Lijan Poltak. 2006. Reformasi Pelayanan Publik (Teori, Kebijakan dan Implementasi). Bumi Aksara. Jakarta. 